\title{
PENGUJIAN KEMBALI VOLATILITAS KEBIJAKAN TRILEMMA TERHADAP VARIABEL MAKROEKONOMI DI INDONESIA
}

\author{
Moch. Syamsudin ${ }^{1}$ \\ Email: mochsyamsudin76@gmail.com
}

\begin{abstract}
The trilemma policy is a hypothesis stating a Mundell-Fleming macroeconomic development framework in which there is a state that cannot simultaneously choose three policies because it must sacrifice one policy so that the realization of policies that leads to economic stability is desired. The research aims to see the effect of the policy volatility on macroeconomic variables in Indonesia. The method used is the vector error correction model (VECM). The results show that the volatility of the trilemma policy adopted by Indonesia in the short and long term Affects the rate of economic growth and inflation. Economic shocks and uncertainties in the world economy externally affect macroeconomic variables. Viewing the results offorecasting for the trilemma policy and macroeconomic variables show that the inflation rate is so high and the level of economic openness is very low. This result recommends that there is a need for harmonization of policies undertaken by Bank Indonesia as the monetary authority and the government as a fiscal authority so as to achieve the level of financial stability that impacts on economic stability.
\end{abstract}

Keywords: Trilemma Policy, Macroeconomics, Vector Error Correction Model (VECM), Forecasting

\section{PENDAHULUAN}

Sejak era globalisasi, krisis keuangan menjadi lebih sering terjadi daripada era sebelumnya. Hal ini timbul karena gangguan keuangan domestik di satu negara dapat mengakibatkan domino effect dengan cara mengacaukan ekonomi terintegrasi lainnya yang mengarah kepada kekacauan keuangan global (Raz et al. 2012). Krisis keuangan dunia pada tahun 2008 memberikan pengalaman untuk menjaga stabilitas sistem keuangan dan ekonomi dunia dari ancaman gejolak keuangan serta meluasnya krisis keuangan ke berbagai negara. Perubahan yang besar pada saat terjadi krisis keuangan yang berdampak pada krisis ekonomi telah menimbulkan penurunan rezim moneter dan memilih untuk menggunakan kombinasi dari tiga tujuan kebijakan trilemma yakni indepensi moneter, stabilitas nilai tukar dan keterbukaan ekonomi yang tercerminn pada tingkat suku bunga yang pruden dimana hal tersebut dikemukakan oleh Mundell's pada tahun 1963 (Aizenman dan Ito 2012). Konsepsi trilemma menyatakan bahwa pembuat kebijakan menghadapi trade off dalam menentukan ketiga tujuannya.

\footnotetext{
${ }^{1}$ Corresponding author: University of Jember, Kalimantan St No. 37, 68121, East Java, Indonesia
} 
Suatu negara tidak mungkin secara bersamaan dapat menargetkan ketiga tujuan tersebut. Pembuat kebijakan dalam hal ini bank sentral hanya dapat mencapai dua tujuan dengan mengorbankan satu atau dua tujuan (Aizenman dan Jinjarak 2014).

Kebijkan trilemma merupakan suatu hipotesis yang menyatakan suatu kerangka pengembangan ekonomi makro Mundell-Fleming yang didalamnya terdapat bahwa negara tidak dapat memilih secara simultan tiga kebijakan karena harus mengorbankan satu kebijakan sehingga terwujudnya kebijakan yang lebih mengarah pada stabilitas ekonomi yang diinginkan. Secara umum, perubahan yang terjadi pada setiap tujuan tersebut termuat dalam konteks "trilemma" (Hsing 2012). Penelitian yang dikemukakan oleh Aizenman et al. (2008) melakukan pengembangan sebuah indeks trilemma yang menyatakan tingkat tiga pilihan kebijakan yang dibuat oleh suatu negara. Penggunaan indeks trilemma tersebut karena setiap konsentrasi pada dua atau tiga indeks antara lain stabilitas nilai tukar, keterbukaan keuangan dan independesi moneter yang mana bank sentral harus mengorbankan salah satu dari ketiganya untuk mencapai tujuan yang telah ditetapkan (Aizenman et al. 2010).

Aizenman (2019) mengungkapkan bahwa negara-negara emerging market telah menerapkan kebijakan moneter yang terintegrasi dengan kebijkan makreoekonomi yang pruden dan menyebabkan terjaganya tingkat inflasi yang diinginkan. Tak terkecuali Indonesia, dimana telah menerapkan tindakan kebijakan trilemma sejak adanya krisis keuangan dunia 2008. Melihat lebih jauh lagi, perkembangan kebijakan trilemma telah membuat Indonesia lebih kuat dalam menanggulangi adanya krisis keuangan dunia 2008. Indeks trilemma di Indonesia yang mana merupakan besaran capaian atas kebijakan moneter yang di dalamnya terdapat independensi moneter, keterbukaan ekonomi dan nilai mata uang yang stabil (Yunita et al. 2017). Berikut ini penjelasan indeks trilemma di Indonesia:

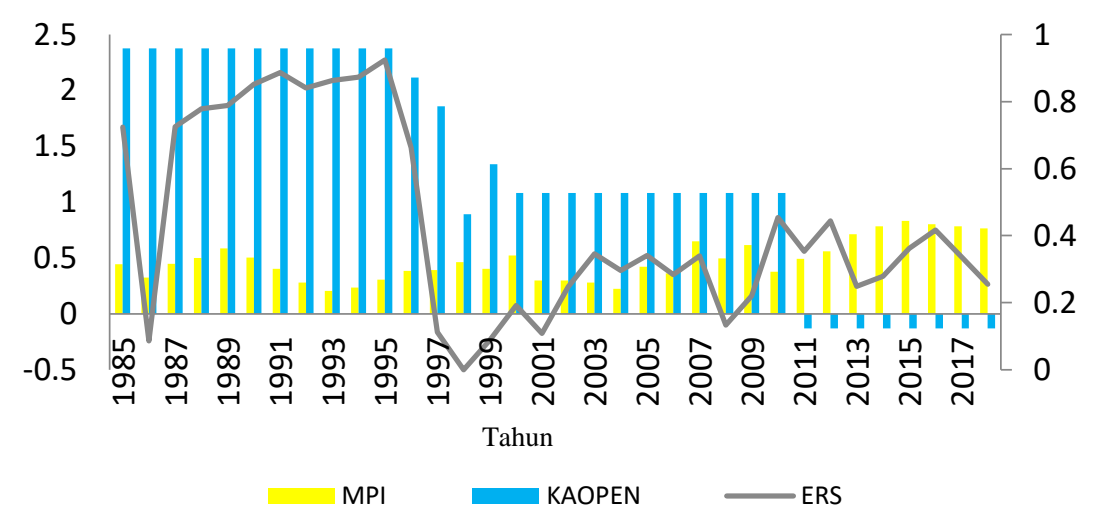

Gambar 1. Perkembangan Kebijakan Trilemma di Indonesia Tahun 1985-2018

Bank Indonesia mempunyai tujuan yakni mencapai dan memelihara kestabilan nilai rupiah. Kestabilan nilai rupiah ini mengandung dua aspek, yaitu kestabilan nilai mata uang terhadap barang dan jasa, serta kestabilan terhadap mata uang negara lain. Aspek pertama tercermin pada perkembangan laju inflasi, sementara aspek kedua tercermin pada perkembangan nilai tukar rupiah terhadap mata uang negara lain (Warjiyo dan Juhro 2016). Berdasarkan tujuan Bank Indonesia tersebut, telah mengakibatkan penurunan jumlah keterbukaan ekonomi yang tercermin dari jumlah penanaman modal asing atau foreign direct investment (FDI). Kebijakan trilemma 
yang dijalankan oleh bank sentral bertolak belakang dengan tujuan dari pemerintah yang mana menetapkan keterbukaan ekonomu melalui menanaman modal asing atau FDI tetap tinggi sehingga mendorong pertumbuhan ekonomi yang semakin tinggi (Yunita et al. 2017).

Pertumbuhan ekonomi dan inflasi yang didasarkan pada bentuk inflasi yang terkendali atau inflation targeting framework (ITF) membuat bank sentral mudah untuk membuat kebijakan trilemma (Cavoli dan Rajan 2008). Penilaian terhadap tingkat inflasi (ITF) dan pertumbuhan ekonomi di Indonesia dilakukan dengan berbagai aspek yakni, konsumsi, investasi, belanja pemerintah dan ekspor-impor. Pertumbuhan ekonomi yang ditopang oleh ekspor minyak yang begitu tinggi mengakibatkan ketergantungan pada satu sumber pendapatan negara (Deliarnov 2006).

Di tengah pembangunan ekonomi yang berdampak pada pertumbuhan ekonomi setelah krisis ekonomi 1997/1998, pada tahun 2008-2009 dunia kembali mengalami kriris ekonomi atau krisis keuangan yang begitu sangat besar (Ali 2018). Perbaikan ekonomi dunia dengan disertai kebijakan yang tidak pasti membuat pertumbuhan ekonomi dan inflasi di Indonesia mengalami sedikit perlambatan setelah terjadinya krisis keuangan tahun 2008-2009.

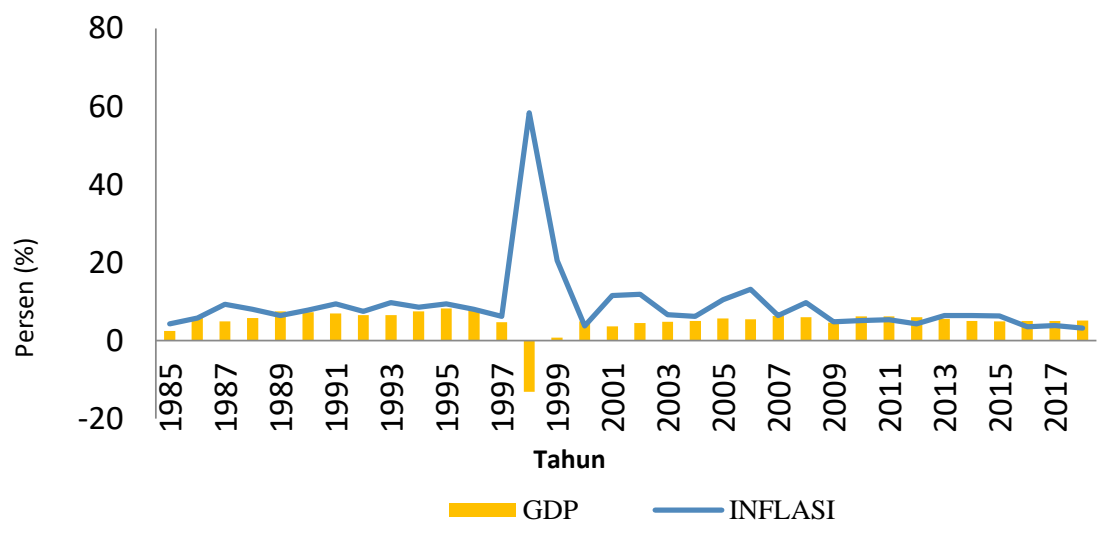

\section{Gambar 2. Pertumbuhan Ekonomi dan Inflasi di Indonesia Pada Tahun 1985 - 2018}

Pertumbuhan ekonomi dan tingkat inflasi yang terjadi pada rentang tahun 2010 hingga 2018 tidak terlepas dari perubahan ekonomi dunia, komposisi ekonomi dalam negeri, politik dalam dan luar negeri hingga fenomena perang dagang antar negara, menyebabkan perekonomian Indonesia bertahan dalam kisaran 5,00\% dan tingkat inflasi yang pruden pada kisaran 3-4\% pada akhir tahun 2018. Didalam merumuskan kebijakan yang bertujuan menstabilkan perekonomian dalam negeri, Bank Indonesia perlu melihat besaran tingkat suku bunga acuan bank sentral Amerika Serikat atau The Fed untuk menentukan besaran tingkat suku bunga dalam negeri. Bank Indonesia mengalami kebingungan dan kekhawatiran mengenai tingka suku bunga yang akan ditetapkan didalam negeri yang mana berguna untuk mengimbangi tingkat suku bunga The Fed. Hal ini yang banyak para ekonom menyebutnya sebagai "Dilema Taper Tantrum" yakni keadaan dimana Bank Indonesia mengalami kebingunan menentukan besaran tingkat suku bunga acuan karena adanya efek pengumuman mengenai kenaikan tingkat suku bunga acuan The Fed. 


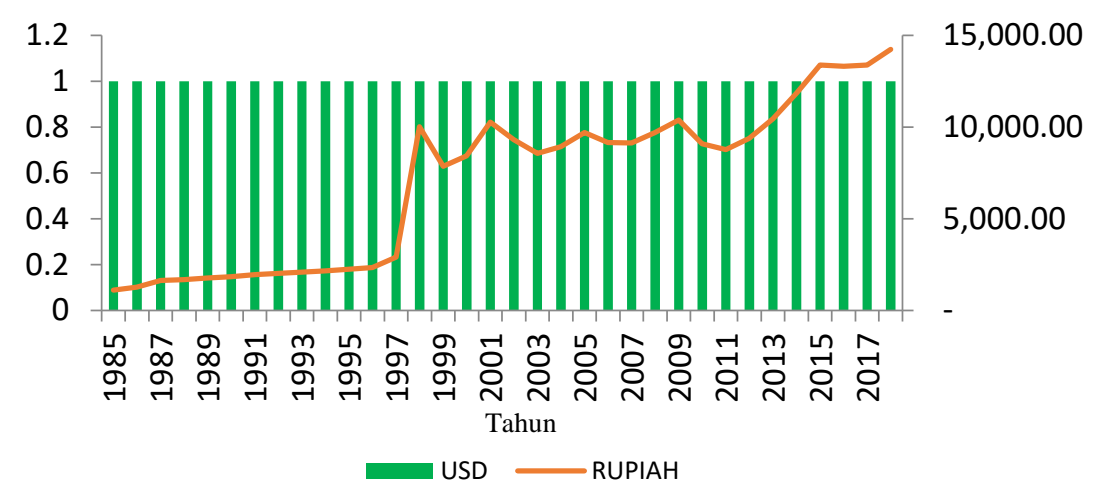

\section{Gambar 3. Pergerakan Nilai Tukar Rupiah Terhadap Nilai Tukar Dollar Amerika Serikat Pada Tahun 1985 Hingga 2018}

Bank Indonesia yang merupakan bank sentral Indonesia telah menerapakan kebijakan moneter yang tertuang dalam kebijakan trilemma. Kebijakan trilemma yang mengharuskan Bank Indonesia mengalami trade off untuk menentukan tujuan yang akan diambil dan mengorbankan satu kebijakan agar tujuannya tercapai (Warjiyo dan Agung 2001). Perubahan kebijakan trilemma yang tidak hanya berdampak pada variabel makroekonomi, juga berdampak pada instrumen moneter lainnya yakni stabilitas nilai tukar Rupiah dan tingkat suku bunga acuan Bank Indonesia. Pengaruh yang begitu kuat diberikan pada saat kebijakan moneter yang ketat dilakukan oleh Bank Indonesia, dimana untuk memberikan jaring pengamanan keuangan pada saat terjadinya guncangan ekonomi (Warjiyo 2003). Pengaman tersebut yakni dengan menekan atau meningkatkan suku bunga acuan Bank Indonesia untuk merespon adanya shock ekonomi yang nantinya berdampak pada stabilitas keuangan nasional.

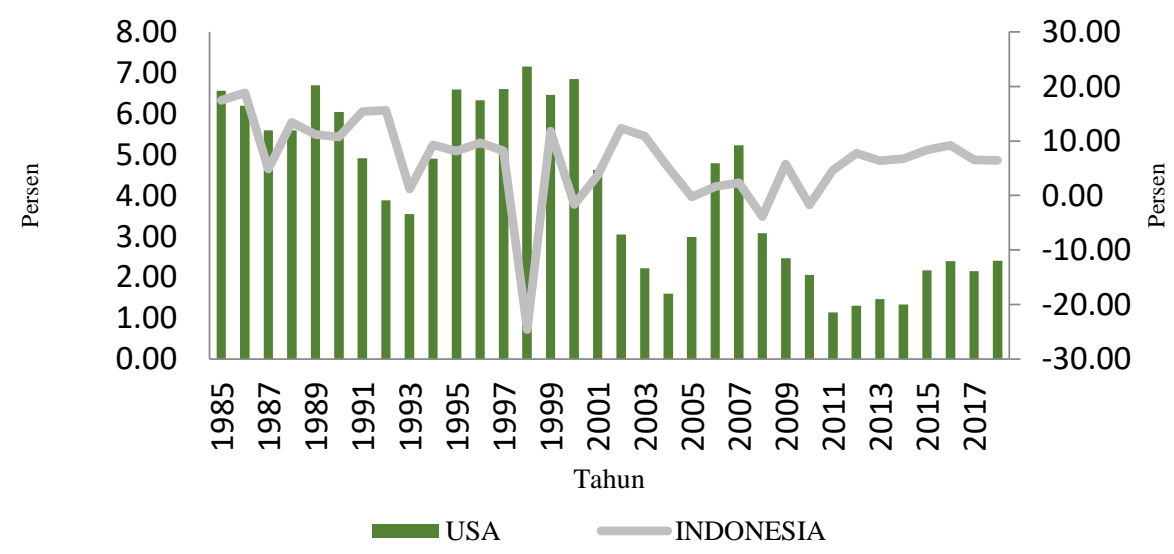

\section{Gambar 4. Pergerakan Tingkat Suku Bunga Acuan Bank Indonesia Dan The Fed Pada Tahun 1985 Sampai 2018}

Penerapan Inflation targeting framework atau lebih dikenal sebagai ITF yang dilakukan oleh Bank Indonesia merupakan suatu kebijakan yang responsif terhadap perubahan atau pengumuman tingkat suku bunga acuan The Fed (Warjiyo dan Juhro 
2016). Perubahan tingkat suku bunga acuan The Fed mendorong setiap negara di dunia untuk melakukan perubahan dengan tujuan menjaga ketersedian Dollar dan menjaga iklim investasi tetap berlangsung.

\section{METODE PENELITIAN}

\section{Jenis dan Sumber Data Penelitian}

Jenis data yang digunakan dalam penelitian ini adalah menggunakan data sekunder. Bentuk data yang digunakan adalah time series dimana dimulai dari tahun 1985 sampai dengan 2018 dengan objek penelitian yakni Indonesia yang datanya diambil secara tahunan. Pengambilan sumber data yang digunakan dalam penelitian ini yakni bersumber dari instansi pemerintah yang telah dipublikasikan oleh World Bank.

\section{Desain Penelitian}

Penelitian volatilitas kebijakan trilemma atau hypothesis trinity berfokus pada variabel makroekonomi di Indonesia yakni pertumbuhan ekonomi (GDP) dan tingkat inflasi. Indikasi dan justifikasi adanya pengaruh di dasari pada bentuk penelitian yang bersifat kuantitatif dengan pendekatan deskriptif statistik dan analisis kuantitatif.

\section{Spesifikasi Model Penelitian}

Model penelitian yang digunakan dalam penelitian ini merujuk pada penelitian terdahulu yang mana model disesuaikan untuk mengidentifikasi dampak kebijakan trilemma yang terlihat berdasarkan indeks trilemma terhadap pertumbuhan ekonomi dan inlfasi di Indonesia. Interaksi kebijakan trilemma terhadap variabel makroekonomi terlihat dalam model yang dikembangkan oleh Julian dan Bogdan yakni:

$$
\mathrm{Y}_{\mathrm{t}}=\mathrm{a}_{0}+\beta_{1} . \mathrm{ERS}_{\mathrm{t}}+\beta_{2} . \mathrm{MPI}_{\mathrm{t}}+\beta_{3} . \mathrm{KAOPEN}_{\mathrm{t}}+e_{\mathrm{t}}
$$

dimana :

$\mathrm{Y}_{\mathrm{t}} \quad=$ variabel makroekonomi yakni pertumbuhan ekonomi dan inflasi,

$\mathrm{ERS}_{\mathrm{t}} \quad=$ indeks stabilitas nilai tukar,

MPI $_{\mathrm{t}}=$ indeks indenpendensi moneter,

$\mathrm{KAOPEN}_{\mathrm{t}} \quad=$ indeks capital mobility,

a $\quad=$ intercep,

$e_{\mathrm{t}} \quad=$ error term

Model diatas dikembangkan kedalam model dasar VAR sebagai berikut :

$$
\mathrm{Y}_{\mathrm{t}}=\beta_{\mathrm{n}} . \mathrm{Y}_{(\mathrm{n}-\mathrm{t})}+e_{\mathrm{t} . .}
$$

Pada persamaan diatas diturunkan kedalam formulasi model VECM untuk mengindentifikasi fenomena trilemma pada variabel makroekonomi sebagai berikut:

$\Delta G D P_{t}=\alpha_{11}+E R S_{(t-1)}+\alpha_{12} K_{A O P E N_{(t-1)}}+\alpha_{13} M P I_{(t-1)}+\alpha_{14} G D P_{(t-1)}+\alpha_{15} \Delta E R S_{(t-1)}$

$+\alpha_{15} \Delta K A O P E N_{(t-1)}+\alpha_{16} \Delta M P I_{(t-1)}+\alpha_{17} \Delta G D P_{(t-1)}+\alpha_{18} \Delta S N T_{(t-n)}+\alpha_{19}$

$$
\begin{aligned}
& \triangle K A O P E N_{(t-n)}+\alpha_{20} \quad \triangle M P I_{(t-n)}+\alpha_{21} \quad \Delta G D P_{(t-n)}+
\end{aligned}
$$

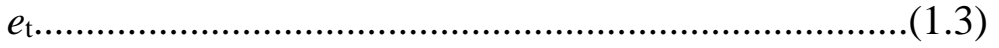

$\Delta I N F_{t}=\alpha_{22}+E R S_{(t-1)}+\alpha_{23} K A O P E N_{(t-1)}+\alpha_{24} M P I_{(t-1)}+\alpha_{25} I N F_{(t-1)}+\alpha_{26} \Delta E R S_{(t-1)}+$ $\alpha_{27} \triangle K A O P E N_{(t-1)}+\alpha_{28} \Delta M P I_{(t-1)}+\alpha_{29} \Delta I N F_{(t-1)}+\alpha_{30} \Delta E R S_{(t-n)}+\alpha_{31}$ $\triangle \operatorname{KAOPEN}_{(t-n)}+\alpha_{32} \quad \Delta M P I_{(t-n)}+\alpha_{33} \Delta I N F_{(t-n)}+$

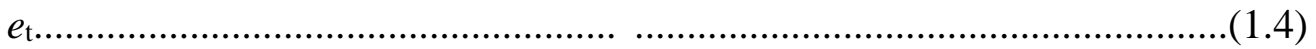




\section{Metode Analisis Data}

Pendekatan kuantitatif adalah pendekatan yang dilakukan dengan cara pencatatan dan penganalisaan data hasil penelitian secara eksak dengan menggunakan perhitungan statistik Sudjana (2004) dan Vector Error Correction Model (VECM) adalah analisis yang digunakan untuk mengestimasi data yang tidak stasioner pada tingkat level, namun memiliki hubungan kointegrasi (Widarjono 2005). Dalam model VECM, dapat melihat hubungan jangka pendek dan jangka panjang yang diberikan oleh variabel independen pada variabel dependen.

\section{HASIL PENELITIAN DAN PEMBAHASAN}

\section{Tingkat Pertumbuhan Ekonomi dan Tingkat Inflasi Yang Dipengaruhi Oleh} Kebijakan Trilemma

Berdasarkan hasil estimasi yang dilakukan dengan model pertumbuhan ekonomi (GDP) dan model inflasi terhadap variabel trilemma yakni stabilitas nilai tukar (ERS), independensi moneter (MPI) dan keterbukaan ekonomi (KAOPEN) dengan alat analisis Vector Error Correction Model (VECM) di indikasikan bahwa tingkat GDP dan inflasi di Indonesia secara jangka pendek dipengaruhi oleh kebijakan trilemma. Ini ditunjukkan pada salah satu hasil model pertumbuhan ekonomi dan model inflasi yang dipengaruhi oleh salah satu dari ketiga kebijkaan trilemma yang dilakukan oleh Bank Indonesia selaku bank sentral. Hasil estimasi tersebut sesuai dengan teori "Trilemma Mundellian" yang menunjukkan bahwa terdapat tradeoff dalam memilih tujuan kebijakan bank sentralnya dengan mendorong pengurangan prioritas pada kebijakan lainnya (Aizenman 2019). Penerapan rezim nilai tukar dan mekanisme kebijakan inflating targeting framework (ITF) di Indonesia terhadap kebijakan bank sentral dalam konteks "Trilemma".

Pengaruh jangka panjang yang diberikan oleh kebijakan trilemma hanya diwakili oleh independensi moneter dan keterbukaan ekonomi terhadap tingkat pertumbuhan ekonomi dan inflasi di Indonesia. Dimana dalam jangka panjang tingkat pertumbuhan ekonomi mengalami pengaruh yang positif terhadap independensi moneter dan dipengaruhi secara negatif oleh keterbukaan ekonomi. Pada tingkat inflasi, independensi moneter memberikan pengaruh yang tidak terlalu signifikan terhadap tingkat inflasi. Untuk keterbukaan ekonomi memberikan tingkat pengaruh yang signifikan terhadap tingkat inflasi tetapi bernilai negatif.

Model Mundell-Fleming menjelaskan tentang mekanisme kebijakan moneter kurang memberikan dampak yang efektif terhadap sistem rezim nilai tukar yang dikelola ketika modal bebas bergerak. Dalam hal ini, paritas tingkat suku bunga acuan perlu mengimbangi tingkat suku bunga acuan bank sentral The Fed untuk menarik international reserves dan capital mobility ke dalam negeri (Aizenman et al. 2008). Kebijakan yang perlu juga dikembangkan adalah tentang makanisme bauran kebijakan fiskal yang lebih progresif karena untuk mengurangi ketergantungan bank sentral dalam menggunakan kebijakan independensi moneter (Aizenman 2019).

\section{Pembahasan Hasil Olah Data pada Kebijakan Trilemma terhadap Variabel Pertumbuhan Ekonomi dan Inflasi di Indonesia Berdasarkan Estimasi Analisis Vector Error Correction Model (VECM)}

Melihat hasil estimasi analisis Vector Error Correction Model (VECM) bahwa terdapat hubungan jangka pendek yang signifikan dan tidak signifikan pada setiap lagnya. Dimana variabel pertumbuhan ekonomi pada lag pertama menunjukkan bahwa 
pada satu periode sebelumnya mempunyai pengaruh yang signifikan dan positif pada salah satu variabel kebijakan trilemma yakni independensi moneter (MPI) yang mana sesuai dengan penelitian yang dilakukan oleh Aizanman pada negara-negara emerging market di Asia pada tahun 2011. Ihnatov dan Căpraru (2014) melakukan penelitian pada negara Eropa Tengah dan Eropa Timur menunjukkan bahwa kebijakan trilemma yang dilakukan oleh bank sentral memengaruhi secara signifikan pada keterbukaan ekonomi (KAOPEN) yang bersifat positif, hal tersebut sesuai dengan hasil penelitian di Indonesia yang menunjukkan adanya pengaruh positif yang diberikan oleh kebijakan trilemma terhadap pertumbuhan ekonomi pada lag ke dua dan lag ke empat namun terdapat pangaruh negatif yang menunjukkan bahwa kebijakan trilemma bank sentral tidak selalu memberikan dampak yang positif pada pertumbuhan ekonomi. Untuk variabel trilemma yakni stabilitas nilai tukar (ERS) memberikan pengaruh pada pertumbuhan ekonomi yang tidak signifikan dan bersifat negatif, hal ini juga sesuai dengan penelitian yang dilakukan oleh Warjiyo dan Juhro (2016) bahwa stabilitas nilai tukar (ERS) yang merupakan tujuan dari Bank Indonesia telah memberikan pengaruh yang negatif karena lebih melindungi nilai tukar Rupiah yang nantinya mencerminkan stabilitas keuangan didalam negeri.

Melihat pendekatan yang dilakukan oleh Mundell-Fleming dan model Dornbusch's Overshooting, bahwa kebijakan moneter lebih difokuskan pada faktor fundamendal dalam penentuan nilai tukar serta seberapa jauh efektivitas kebijakan moneter dan fiskal dalam menstabilkan output (Warjiyo dan Juhro 2016). Kerangka analisis yang digunakan untuk mengindetifikasi adanya hubungan pada kebijakan trilemma yang digunakan pada sistem ekonomi terbuka. Hal tersebut mengalami suatu pertentangan dengan rumusan yang dilakukan oleh Tinbergen untuk ekonomi tertutup bahwa hanya ada satu instrumen kebijakan moneter hanya untuk satu tujuan, sehingga dalam ekonomi terbuka lebih memfokuskan pada suatu kebijakan yang ditentukam berdasarkan pertimbangan sistem nilai tukar dan devisa yang diterapkan (Warjiyo dan Juhro 2016). Dengan kata lain efektifitas kebijakan moneter dalam memengaruhi output hanya berlaku apabila suatu negara yang bersangkutan menganut sistem nilai tukatr fleksibel (managing floting exchange rate) dan sistem devisa bebas (Warjiyo dan Juhro 2019).

Melihat hasil analisis menggunakan VECM tersebut, terdapat hubungan jangka pendek yang signifikan dan tidak signifikan pada setiap lagnya. Hasil tersebut juga terdapat kesesuaian pada penelitian yang dilakukan oleh Warjiyo (2013) bahwa penerapan floting exchange rate telah berdampak pada inflasi yang kurang baik karena bank sentral tidak dapat mengintervensi pasar dalam mengendalikan nilai tukar. Pada lag ke dua dan ke tiga, variabel inflasi dipengaruhi oleh keterbukaan ekonomi (KAOPEN) yang befariatif, bahwa terjadi pangaruh signifikan bersifat positif atau negatif dan pengaruh tidak signifikan bersifat positif dan nagatif. Ini juga sesuai dengan hasil penelitian yang dilakukan oleh Yunita et al. (2017) dimana variabel inflasi mengalami volatilitas yang dipengaruhi oleh salah satu kebijakan trilemma bank sentral Indonesia karena penerapan rezim mangambang bebas (managing free floating exchange rate) di Indonesia terhadap kebijakan dalam konteks "trilemma" (Aizenman 2019). Mengenai hal tersebut, konsep kebijakan trilemma berbenturan dengan kebijakan bank sentral dalam mengontrol tingkat inflasi yang telah ditentukan atau inflating targeting framework (ITF) (Warjiyo 2013). Kebijakan ITF yang memiliki banyak makna dan implikasi tertuang dalam mekanisme difusi dari fundamental moneter yang diajalankan (Warjiyo dan Juhro 2019). Dimana kebijakan 
moneter harus mencapai kesesuaian yang tertuang dalam ITF yang diumumkan kepada publik dalam bentuk undang-undang dan diharmonisasikan dengan kebijakan fiskal yang progresif.

\section{Dampak Kebijakan Trilemma Terhadap Tingkat Pertumbuhan Ekonomi dan Inflasi}

Kebijakan trilemma yang berdampak pada tingkat pertumbuhan ekonomi dan tingkat inflasi dapat terlihat pada seberapa lama efek dari kebijakan trilemma tersebut memengaruhi pertumbuhan ekonomi dan inflasi di Indonesia. Dengan melalui hasil estimasi yang dilakukan dengan model pertumbuhan ekonomi dan inflasi dengan variabel kebijakan trilemma terlihat adanya respon yang berfariatif. Shock ekonomi atau guncangan ekonomi yang diberikan akibat kebijakan trilemma terhadap pertumbuhan ekonomi dan inflasi dikarenakan masih rapuhnya perekonomian Indonesia terhadap volatilitas kebijakan moneter yang dilakukan oleh Bank Indonesia. Dimana stabilitas nilai tukar yang mencerminkan salah satu tujuan dari Bank Indonesia untuk menciptakan stabilitas sistem keuangan perlu untuk di harmonisasikan dengan intervensi bank sentral di pasar valas (Juhro dan Aulia 2017).

Penelitian lain dari Yunita et al. (2017) menunjukkan bahwa Indonesia yang masih tergolong negara dengan penghasilan menengah atau middle income, efektivitas dari transmisi kebijakan moneter dalam jangka pendek dan panjang melaui jalur tingkat suku bunga acuan belum tercapai. Hal ini juga mendorong Bank Indonesia untuk membuka atau melonggarkan sistem devisa sehingga menarik investasi masuk ke dalam negeri. Keterbukaan ekonomi yang dilakukan oleh Bank Indonesia dapat berbentuk foreign direct investmen (FDI) atau international reserves (Wardhono 2004). Masuknya aliran modal asing ke dalam negeri secara tidak langsung akan memberikan multiplayer effect pada tingkat pertumbuhan ekonomi dikarenakan penggunaan modal asing dalam pembangunan ekonomi akan meningkatkan pertumbuhan ekonomi secara tidak langsung (Khandelwal et al. 2004).

\section{Kombinasi Kebijakan Trilemma Di Indonesia Terhadap Stabilitas Makroekonomi}

Kombinasi kebijakan moneter pada dasarnya memiliki pola yang beragam. Berbagai faktor dapat dijelaskan bahwa kebijakan trilemma bukan hanya satu-satunya kebijakan yang memberikan pengaruh pada variabel makroekonomi (Hsing 2012). Teori Fredman tentang faktor inflasi juga menjelaskan bahwa pertumbuhan ekonomi, investasi dan belanja pemerintah sangan dipengaruhi oleh tingkat atau seberapa besar inflasi yang terjadi (Mankiw 2017). Pada setiap kombinasi kebijakan yang diambil, pada akhirnya akan memberikan pola tekanan pada kebijakan Trilemma yang dilakukan oleh bank sentral pada suatu negara. Pertimbangan yang dilakukan oleh bank sentral secara baik melihat dari kondisi internal ataupun eksternal bank sentral yang nantinya merubah pola-pola inetraksi atau dampak bauraana kebijakan yang telah ada sebelumnya (Ito dan Kawai 2014; Aizenman 2019). 


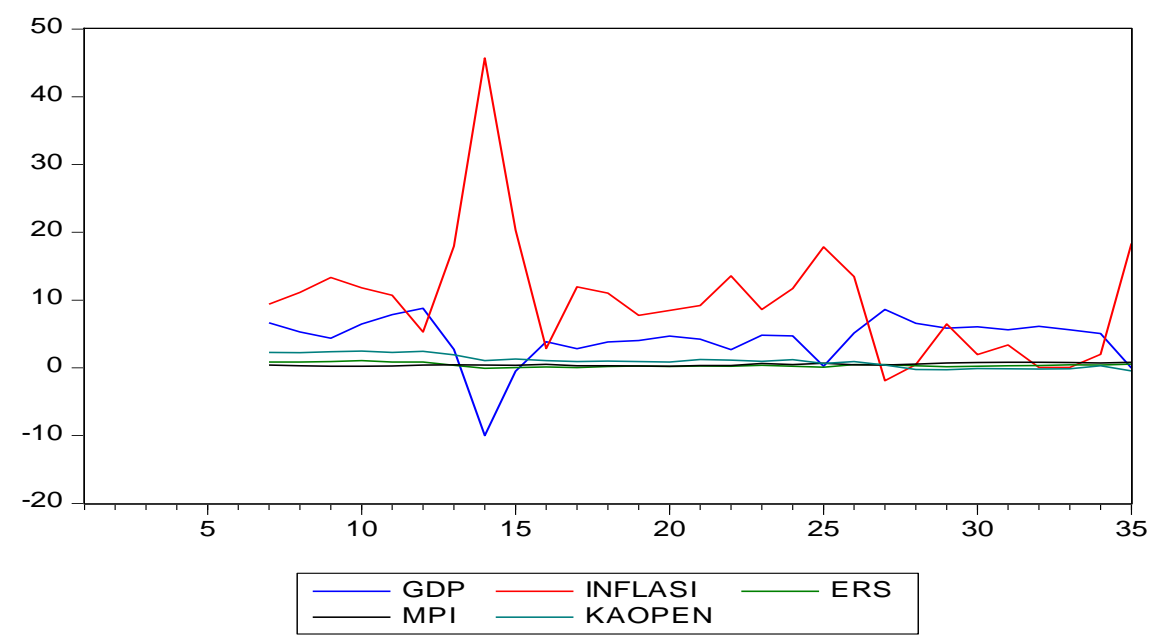

Gambar 5. Hasil Forecasting Esimasi VECM Model Pertumbuhan Ekonomi, Inflasi Dan Kebijakan Trilemma di Indonesia (Sumber: Data Diolah)

Dengan pendekatan estimasi VECM, hasil kebijakan trilemma di Indonesia yang begitu bervolatilitas dapat diprediksi pada satu tahun yang akan datang dan juga dapat diprediksi memberikan pengaruh pada variabel makroekonomi yakni pertumbuhan ekonomi dan inflasi di Indonesia. Dimana hasil estimasi VECM untuk prediksi tingkat pertumbuhan ekonomi, tingkat inflasi dan indeks kebijakan trilemma menunjukkan adanya penurunan dari pertumbuhan ekonomi di tahun yang akan datang dan tingkat inflasi mengalami kenaikan yang cukup signifikan di tahun yang akan datang. Variabel kebijakan trilemma yakni stabilitas nilai tukar (ERS), independesi moneter (MPI) dan keterbukaan ekonomi (KAOPEN) masing-masing sebesar 0,55\%, $0,83 \%$ dan $-0,46 \%$. Hal ini di indikasikan bahwa kebijakan trilemma yang diberlakukan oleh Bank Indonesia dengan pendekatan model Mundell's-Flaming yakni masih mengorbankan keterbukaan ekonomi dan memilih untuk menstabilkan nilai tukar dan independesi moneter sebagai tujuan utama. Perubahan pertumbuhaan ekonomi dan tingkat inflasi berdasarkan hasil penerapan kebijakan trilemma berdampak pada turunnya tingkat pertumbuhan ekonomi dan meningkatkan inflasi.

Penentuan kebijakan trilemma yang dilakukan oleh Bank Indonesia juga harus mengedepankan tujuan dari Bank Indonesia dalam memelihara dan mencapai stabilitas nilai tukar yang nantinya berdampak pada stabilitas keuangan. Adanya trade off kebijakan yang dilakukan Bank Indonesia dalam menuntukan rezim nilai tukar juga berdampak pada kebijakan trilemma yang akan diterapkan. Perubahan rezim nilai tukar dari free floating ke managed floating yang artinya bank sentral melakukan intervensi di pasar valas sebagai bentuk tujuan dari Bank Indonesia (Warjiyo dan Juhro 2016). Terlepas dari pengaruh kebijakan trilemma yang dilakukan oleh Bank Indonesia, tingkat pertumbuhan ekonomi dan inflasi di Indonesia juga sangat dipengaruhi oleh gejolak perekonomian dan geopolitik dunia. Ketidakpastian penentuan kebijakan, volatilias harga minyak dunia, penurunan komoditas dunia hingga perang dagang yang berlangsung antar negara telah memberikan dampak yang sangat kuat terhadap pertumbuhan ekonomi dan tingkat inflasi di Indonesia. 


\section{SIMPULAN, KETERBATASAN, DAN SARAN}

Hipotesis Mundell's-Flaming trilemma telah memberikan jawaban mengenai penggunaan kebijakan trilemma yang dianggap sebagai sebuah cara bagi Bank Indonesia menerapkan kebijakan moneter yang sesuai dengan keadaan perkembangan ekonomi dunia. Dimana kebijakan trilemma yang dilakukan oleh bank sentral Indonesia telah memberikn pengaruh pada variabel pertumbuhan ekonomi dan tingkat inflasi. Berdasarkan analisis diatas, kesimpulan penting didapat dalam penelitian ini menggunakan analisis deskriptif dan metode Vector Error Correction Model (VECM) terdapat dua poin utama yang disimpulkan dalam penelitin ini sebagai berikut :

1. Konfigurasi kebijakan yang dilakukan oleh Bank Indonesia sesuai dengan hipotesis Mundell's-Fleming mengalami fluktuatif yang tinggi di Indonesia, terutama dipengaruhi oleh shock ekonomi pada tahun 1997-1998 dan krisis keuangan dunia pada tahun 2008-2009. Pertumbuhan ekonomi yang merosot tajam dan diperparah dengan tingginya tingkat inflasi, memberikan dampak yang kuat pada kebijakan moneter yang akan dikeluarkan oleh Bank Indonesia selaku otoritas pembuat kebijakan moneter di Indonesia. Dimana Bank Indonesia dengan menggunakan bauran kebijakan moneter yakni instrumen kebijakan trilemma mengharuskan memilih dua kebijakan dan mengorbankan satu kebijakan yang nantinya memberikan pengaruh pada pertumbuhan ekonomi dan tingkat inflasi di Indonesia.

2. Dalam pengaruh kebijakan trilemma terhadap variabel pertumbuhan ekonomi dan inflasi di Indonesia memberikan jawaban yang bervariatif. Dimana pada variabel kebijakan trilemma yakni stabilitas nilai tukar, independesi moneter dan keterbukaan ekonomi dalam jangka pendek dan jangka panjang saling memengaruhi tingkat pertumbuhan ekonomi dan tingkat inflasi. Pengaruh tersebut dilihat berdasarkan metode Vector Error Correction Model (VECM) yang mana bank sentral Indonesia mengalami trade off untuk menentukan kebijakan yang akan diambil pada setiap tahunnya. Untuk hasil prediksi berdasarkan analisis VECM tersebut, bahwa kebijakan trilemma yang akan dilakukan oleh Bank Indonesia mengorbankan keterbukaan ekonomi dan memilih stabilitas nilai tukar dan independensi moneter sebagai yang terbaik. Secara empiris hal tersebut sesuai dengan penelitian yang dilakukan oleh (Beck dan Prinz 2012; Han dan Wei 2018).

\section{DAFTAR PUSTAKA}

Aizenman, J. 2019. A modern reincarnation of Mundell-Fleming's trilemma. Economic Modelling 81:444-454.

Aizenman, J., M. D. Chinn, dan H. Ito. 2008. Assessing the emerging global financial architecture: Measuring the trilemma's configurations over time: National Bureau of Economic Research.

- 2010. The emerging global financial architecture: Tracing and evaluating new patterns of the trilemma configuration. Journal of International Money Finance 29 (4):615-641.

Aizenman, J., dan H. Ito. 2012. Trilemma policy convergence patterns and output volatility. The North American Journal of Economics Finance 23 (3):269-285.

Aizenman, J., dan Y. Jinjarak. 2014. Real estate valuation, current account and credit growth patterns, before and after the 2008-9 crisis. Journal of International Money Finance 48:249-270. 
Ali, F. 2018. Ekonomi Politik Indonesia: Sketsa Historis dan Masa Depan. Jawa Timur: Intrans Publishing.

Beck, H., dan A. Prinz. 2012. The trilemma of a monetary union: Another impossible trinity. Intereconomics 47 (1):39-43.

Cavoli, T., dan R. S. Rajan. 2008. Open economy inflation targeting arrangements and monetary policy rules. Indian Growth Development Review 1 (2):237-251.

Deliarnov. 2006. Ekonomi Politik: Mencakup Berbagai Teori dan Konsep yang Komprehensif. Jakarta: Erlangga.

Han, X., dan S.-J. Wei. 2018. International transmissions of monetary shocks: Between a trilemma and a dilemma. Journal of International Economics 110:205-219.

Hsing, Y. 2012. Impacts of the trilemma policies on inflation, growth and volatility in Greece. International Journal of Economics Financial Issues 2 (3):373.

Ihnatov, I., dan B. Căpraru. 2014. The trilemma policies and macroeconomic volatility in Central and Eastern Europe. Procedia Economics Finance 15:853-857.

Ito, H., dan M. Kawai. 2014. Determinations of the Trilemma Policy Combination: ADBI Working Paper 381. Asian Development Bank Institute.

Juhro, S. M., dan A. Aulia. 2017. Transformational leadership through applied neuroscience: Transmission mechanism of the thinking process.

Khandelwal, S. K., H. P. Jhingan, S. Ramesh, R. K. Gupta, dan V. K. Srivastava. 2004. India Mental Health Country Profile. International review of psychiatry 16 (12):126-141.

Mankiw, N. G. 2017. Macroeconomics Ninth Edition. New York: Worth Publisher.

Raz, A. F., T. P. Indra, D. K. Artikasih, dan S. Citra. 2012. Global financial crises and economic growth: Evidence from East Asian economies. Buletin Ekonomi Moneter Dan Perbankan 15 (2):35-54.

Sudjana. 2004. Meoda Statistika. Bandung: PT Tarsito.

Wardhono, A. 2004. Mengenal Ekonometrika Edisi Pertama. Jember: Fakultas Ekonomi Universitas Jember.

Warjiyo, P. 2003. Kebijakan moneter di indonesia. Vol. 6: Pusat Pendidikan Dan Studi Kebanksentralan (PPSK) Bank Indonesia.

. 2013. Indonesia: Stabilizing The Exchange Rate Along Its Fundamental. BIS Paper.

Warjiyo, P., dan J. Agung. 2001. Transmission Mechanisms of Monetary Policy in Indonesia: Financial Market Structuring and Development Studies Division, Directorate.

Warjiyo, P., dan S. M. Juhro. 2016. Kebijakan Bank Sentral: Teori dan Praktik. Jakarta: Rajawali Press.

Warjiyo, P., dan S. M. Juhro. 2019. Central Bank Policy: Theory and Practice: Emerald Group Publishing.

Widarjono, A. 2005. The impact of real exchange rate on trade balance. Jurnal Ekonomi dan Bisnis Indonesia 20 (2005).

Yunita, M., N. A. Achsani, dan L. Anggraeni. 2017. Pengujian Trilemma Conditions pada Perekonomian Indonesia. Jurnal Ekonomi dan Pembangunan Indonesia 17 (2):151-168. 